\title{
Protective Properties of Probiotics on Commercial Broilers Experimentally Infected With Salmonella Enteritidis
}

\author{
Okuneye $\mathrm{OJ}^{* 1}$, Oloso $\mathrm{NO}^{2}$, Adekunle $\mathrm{OF}^{1}$, Ogunfolabo $\mathrm{LA}^{1}$, Fasanmi $\mathrm{OG}^{* 1,2}$ and Ishola $\mathrm{OO}^{3}$ \\ ${ }^{1}$ Federal College of Animal Health \& Production Technology, Ibadan, Nigeria \\ ${ }^{2}$ Department of Production Animal Studies, University of Pretoria, Pretoria, South Africa \\ ${ }^{3}$ Department of Veterinary Public Health \& Preventive Medicine, Faculty of Veterinary Medicine, University of \\ Ibadan, Ibadan, Nigeria
}

${ }^{*}$ Corresponding author: Okuneye OJ and Fasanmi OG, Federal College of Animal Health \& Production Technology, Ibadan, Nigeria, Tel: +27625047537, +2348033194514, E-mail: bumaetal@gmail.com, u15340482@tuks.co.za

Citation: Okuneye OJ, Oloso NO, Adekunle OF, Ogunfolabo LA, Fasanmi OG, et al. (2016) Protective Properties of Probiotics on Commercial Broilers Experimentally Infected With Salmonella Enteritidis. J Vet Sci Anim Husb 4(3): 307

Received Date: October 25, 2016 Accepted Date: November 28, 2016 Published Date: November 30, 2016

\begin{abstract}
Performance and productivity in the poultry industry lately is predicated on the use of antimicrobials, which has led to various negative impacts; among which include the emergence of a variety of pathogens and bacterial resistance including salmonella sp. This study was designed to investigate periodic evaluation of the protective properties of probiotic on commercial broilers experimentally infected with Salmonella Enteritidis; specifically on bacterial shedding and mortality pattern of birds throughout the rearing period. One hundred and eighty day old commercial broilers were allotted into four treatment groups, G1 (antibiotics, probiotic \& $S$. Enteritidis infected), G2 (antibiotics \& S. Enteritidis infected), G3 (probiotic \& S. Enteritidis infected) and G4 (antibiotics) each replicated thrice, with 15 birds per replicate. Antibiotic and probiotics were administered day 1-5 and 6-56 days respectively; thereafter, cultured Salmonella Enteritidis was inoculated at the dose rate of $107 \mathrm{cfu}$ orally. This study lasted for eight (8) weeks, during which freshly voided faecal samples were collected from the respective replicates for isolation, biochemical test and salmonellae counts; for pre-infection (0), 7, $10,15,18$ and 21 day post infection (dpi). Data generated were subjected to descriptive statistical analysis and significant differences $(p<0.05)$ between mean values determined with student $t$-test. The numbers of dead birds over a period of 8 weeks were calculated and expressed as percentage of allotted birds in each treatment group.

The results showed that G1 had the best performance with lowest mortality (4\%) and least faecal salmonella count irrespective of dpi at $\mathrm{p}<0.05$; G3 is not different from G1 in salmonellae count, but has a total mortality of $13 \%$. The worst result was recorded in G2 (Control) with highest salmonellae count $(\mathrm{p}<0.05)$ and mortality $(37 \%)$. It can therefore be concluded that Probiotic supplementation in broiler ration improves the liveability of broilers through elimination and/or reduction of gut salmonellae.
\end{abstract}

Keywords: Broilers; Faecal shedding; Mortality; Probiotic; Salmonella Enteritidis

\section{Introduction}

Salmonellosis is an important socioeconomic problem in several counties, especially in third world countries; it is responsible for food-borne disease outbreaks. It is one of the most problematic zoonosis in terms of public health all over the world because of the high endemicity and difficulty in combating it [1-5]. Salmonellosis is a disease which affects all warm blooded animals, and caused by several Salmonella sp., field and laboratory reports suggest that poultry meat remains as the main cause of human salmonella food poisoning, with Salmonella Enteritidis mostly implicated; and transmitted vertically and horizontally in poultry with high mortality [2,4,6-13].

Due to an avalanche of concerns on food safety, stake holders in the poultry industry, consumers and decision makers arrived at a common front; leading to the possibility of stopping the use of antibiotics as growth stimulants for poultry and the concern about the side-effects of their use as therapeutic agents has led to the introduction of control measures and alternatives to combat salmonellosis; and probiotics considered [14-17].

Probiotics have beneficial effects on broiler performance, regulation and improvement of the immune system, intestinal microflora and pathogen inhibition and the mechanism of action is through selective or competitive exclusion [16,18-31]. 
This study therefore seeks to investigate periodic evaluation of the protective properties of probiotic on commercial broilers experimentally infected with Salmonella Enteritidis; specifically; on bacterial shedding and mortality pattern of birds throughout the rearing period.

\section{Materials and Methods}

\section{Study locations and materials}

One hundred and eighty day old Marshal commercial broilers were purchased from Agrited hatcheries, Ibadan and the rearing and experiment took place in a well-constructed compartmentalized open sided poultry cages, with a wire mesh floor, and tray below well suited for this experimentation, in Ibadan, Nigeria. The allotted 15 birds per replicate were housed in the same cage; so there were 3 cages per treatment group and 12 cages in all for the study. This study was conducted between May - July, 2015; and spanned through eight weeks. Birds were randomly selected and distributed into four treatment groups (G1, G2, G3 and G4) respectively; with each replicated thrice, and fifteen birds were allotted per replicate. Birds were housed inside cages intensively throughout the study period; they were given water, fed broiler starter and finisher rations as at when due ad libitum and exposed to just 12 hours of day lights. The probiotic used is feed-grade lactobacilli $\left(\mathrm{TGI}^{\odot}\right)$. Find below the layout of experiment and treatment pattern $($ Table 1).

\begin{tabular}{|c|c|c|c|}
\hline Group & $\begin{array}{c}\text { Antibiotic } \\
\text { (day 1-5) }\end{array}$ & $\begin{array}{c}\text { Probiotics } \\
\text { (day 6- end) }\end{array}$ & $\begin{array}{c}\text { Salmonella } \\
\text { enteritidis }\end{array}$ \\
\hline G1 & + & + & + \\
\hline G2 & + & - & + \\
\hline G3 & - & + & + \\
\hline G4 & + & - & - \\
\hline \\
Table 1: Layout of experiment and treatment pattern
\end{tabular}

Birds were housed inside cages intensively throughout the study period; they were given water, fed broiler starter and finisher rations as at when due ad libitum and exposed to just 12 hours of day lights. The probiotic used is feed-grade lactobacilli (TGI ${ }^{\circledR}$ )

The antibiotics used is Anicillin ${ }^{\oplus}(100 \mathrm{~g} / 200$ litres of water), administered in the drinking water and the probiotics (500g/tonne of feed); both sourced from AnimalCare Konsult, Ogere, Nigeria. Thereafter, cultured Salmonella Enteritidis with serial dilution of $10^{7} \mathrm{cfu}$, obtained from the Laboratory of Animal Care Services was administered orally through drinking water.

\section{Faecal sample collection}

Faecal droppings were collected separately in the trays directly under each unit; sterile spatulas and gloves were used to collect samples of freshly passed poultry droppings in well labelled sterile universal sampling bottles. The droppings were collected at random points, sealed, stored in ice packs and transported to the Nigeria Institute of Science laboratory Technology, Ibadan and the Food and Meat Hygiene laboratory of Department of Veterinary Public health and preventive medicine, University of Ibadan, Nigeria, where they were analysed within one hour from the time of collection. Three samples were taken per replicate, making a total of 36 samples in all for analyses.

\section{Sample analysis}

The isolation of Salmonella from poultry faecal samples was carried out according to the method described by Barrell and Steigh, et al. $[32,33]$. $1 \mathrm{~g}$ was taken from each faecal sample and added to $9 \mathrm{ml}$ of Selenite F broth ((LAB M, Bury, UK. Product code Lab $44 \mathrm{~A})$; and incubated overnight before serial dilution and subculture plating on MacConkey agar.

The plates were incubated at $37{ }^{\circ} \mathrm{C}$ for 24 hrs. Growth patterns of Salmonella-typical colonies were identified on the plates morphologically and through the colouration (greyish to colourless). These were further subjected to biochemical tests (such as triple sugar iron agar (TSIA) [LAB M, Bury, UK.] slants, urea agar (Oxoid m53), lysine broth and were incubated at $37^{\circ} \mathrm{C}$ for $24 \mathrm{~h}$. The suspected Salmonella colonies were hydrogen sulphide positive on TSIA and urease negative); also motility tests was carried out and they are positive. Growths on the media were subsequently counted, colony forming units (CFU) were calculated considering appropriate dilution factors; the mean CFU/ml were determined from the average of the sum of the replicates per group and were transformed into $\log \mathrm{cfu} / \mathrm{ml}$. Samples were collected on day 0 (pre-infection), and days 7, 10, 15, 18 and 21 post infection (dpi); and analyses carried out as described above.

\section{Statistical analysis}

The number of colonies grown on MacConkey agar recorded as mean cfu/ml and log cfu/ml. They were subsequently subjected to analysis were using Statistical Package for Social Sciences (S.P.S.S) version 11. Descriptive Statistics was employed in analysing the data and student t-test were conducted for the generated data to determine significant differences between means of faecal 
salmonellae counts of treatment groups, A p-value of $\mathrm{p}<0.05$ was considered significant.. The numbers of dead birds over a period of 8 weeks were calculated and expressed as percentage of allotted birds in each treatment group.

\section{Results}

Following the allotment of one hundred and eighty (180) day old Marshal broilers into four treatment groups and replicated thrice; treatment groups were placed on different treatment patterns (Table 1). Collected faecal samples from respective treatment groups were subjected to laboratory procedures for morphological and biochemical identification; motility test and numerical counting following growth on MacConkey culture media, this was done 0, 7, 10, 15, 18 and 21 dpi (Figure 1). Data collected thereof were recorded as mean $\mathrm{cfu} / \mathrm{ml}$ and $\log \mathrm{cfu} / \mathrm{ml}$, and subsequently subjected to descriptive statistical analysis; student $\mathrm{t}$-test was conducted for the generated data to determine significant differences at 95\% confidence limit. Results are as listed below viz;

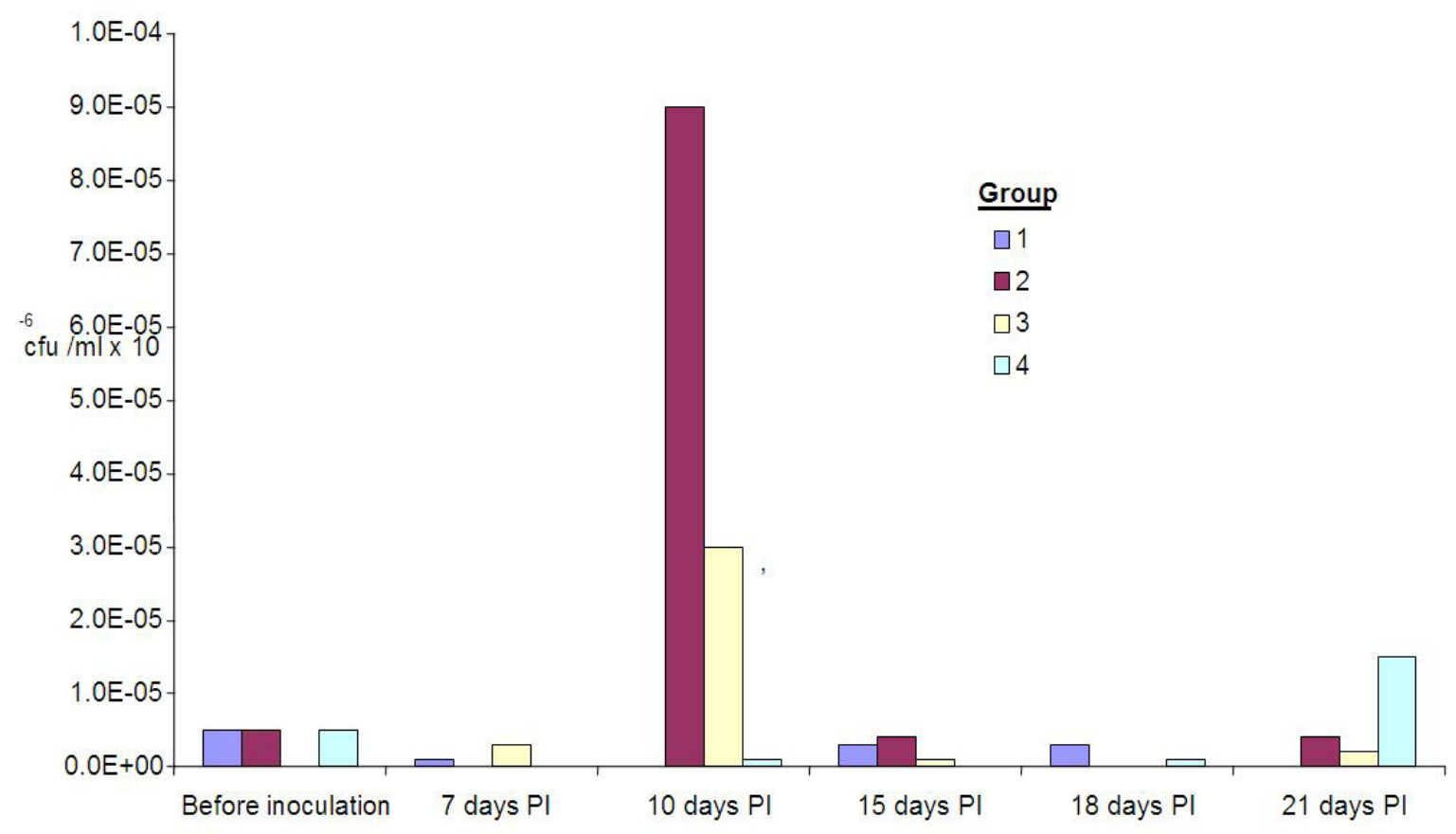

Figure 1: Samonellae count versus dpi of broilers fed antibiotic/probiotic

The Salmonellae count in faecal materials of broilers in the different treatment groups pre-infection with Salmonella enteritidis show that there were no significant differences among and across the treatment groups at $p>0.05$ (Table 2). Table 3 shows the Salmonellae count in faecal materials of broilers in the different treatment groups 7 days post-infection with Salmonella enteritidis; there were no significant differences among and across the treatment groups also at $\mathrm{p}>0.05$. However at 10 days post infection of the broilers, Table 4 shows that Salmonellae count in faecal materials of broilers in the different treatment groups have significant differences ( $p<0.05$ ), especially with treatment group 1 (G1) different from G2, G3 and G4, with G1 having a Log cfu of $7.78 \pm 0.36$, while the other treatments are not different from one another.

\begin{tabular}{|c|c|c|c|c|}
\hline Group & $\begin{array}{c}\text { Mean CFU } \\
/ \mathbf{m l}\end{array}$ & $\begin{array}{c}\text { LogCFU } \\
\text { mean } \pm \text { SEM }\end{array}$ & t-value & P \\
\hline 2 & $4.5 \times 10^{6}$ & $3.48 \pm 0.347$ & 0.000 & $>.05$ \\
\hline 1 & $4.5 \times 10^{6}$ & $3.48 \pm 0.347$ & & \\
\hline 3 & $0.0 \times 10^{6}$ & $0.00 \pm 0.0 .00$ & -1.000 & $>.05$ \\
\hline 1 & $4.5 \times 10^{6}$ & $3.48 \pm 0.347$ & & \\
\hline 3 & $0.0 \times 10^{6}$ & $0.00 \pm 0.00$ & 1.000 & $>.05$ \\
\hline 2 & $4.5 \times 10^{6}$ & $3.48 \pm 0.347$ & & \\
\hline 4 & $4.5 \times 10^{6}$ & $3.48 \pm 0.347$ & 0.000 & $>.05$ \\
\hline 1 & $4.5 \times 10^{6}$ & $3.48 \pm 0.347$ & & \\
\hline 4 & $4.5 \times 10^{6}$ & $3.48 \pm 0.347$ & 0.000 & $>.05$ \\
\hline 2 & $4.5 \times 10^{6}$ & $3.48 \pm 0.347$ & & \\
\hline 4 & $4.5 \times 10^{6}$ & $3.48 \pm 0.347$ & 1.000 & $>.05$ \\
\hline 3 & $0.0 \times 10^{6}$ & $0.00 \pm 0.000$ & & \\
\hline
\end{tabular}

Table 2: Salmonellae count for broilers fed antibiotic/probiotic before infection 


\begin{tabular}{|c|c|c|c|c|}
\hline Group & Mean CFP $/ \mathbf{m l}$ & LogCFU (mean \pm SEM $)$ & t-value & P \\
\hline 2 & $0.0 \times 10^{6}$ & $0.00 \pm 0.00$ & -1.000 & $>.05$ \\
\hline 1 & $1.0 \times 10^{6}$ & $3.67 \pm 0.36$ & & \\
\hline 3 & $2.5 \times 10^{6}$ & $3.85 \pm 0.38$ & 0.037 & $>.05$ \\
\hline 1 & $1.0 \times 10^{6}$ & $3.67 \pm 0.36$ & & \\
\hline 3 & $2.5 \times 10^{6}$ & $3.85 \pm 0.38$ & 1.000 & $>.05$ \\
\hline 2 & $0.0 \times 10^{6}$ & $0.00 \pm 0.00$ & & \\
\hline 4 & $0.0 \times 10^{6}$ & $0.00 \pm 0.00$ & 0.000 & $>.05$ \\
\hline 1 & $1.0 \times 10^{6}$ & $3.67 \pm 0.36$ & & \\
\hline 4 & $0.0 \times 10^{6}$ & $0.00 \pm 0.00$ & -1.000 & $>.05$ \\
\hline 2 & $1.0 \times 10^{6}$ & $3.48 \pm 0.35$ & & \\
\hline 4 & $0.0 \times 10^{6}$ & $0.00 \pm 0.00$ & -1.000 & $>.05$ \\
\hline 3 & $2.5 \times 10^{6}$ & & & \\
\hline
\end{tabular}

dpi- day post-infection

Table 3: Salmonellae count for broilers fed antibiotic/probiotic 7 dpi

\begin{tabular}{|c|c|c|c|c|}
\hline Group & Mean CFP / ml & LogCFU (mean \pm SEM) & t-value & P \\
\hline 2 & $0.0 \times 10^{6}$ & $0.00 \pm 0.00$ & $25.84^{*}$ & $<.05$ \\
\hline 1 & $7.5 \times 10^{6}$ & $7.78 \pm 0.36$ & & \\
\hline 3 & $2.0 \times 10^{6}$ & $7.24 \pm 0.239$ & $30.35^{*}$ & $<.05$ \\
\hline 1 & $7.5 \times 10^{6}$ & $7.78 \pm 0.36$ & & \\
\hline 3 & $2.0 \times 10^{6}$ & $7.24 \pm 0.239$ & -1.41 & $>.05$ \\
\hline 2 & $0.0 \times 10^{6}$ & $0.00 \pm 0.00$ & & \\
\hline 4 & $1.0 \times 10^{6}$ & $3.48 \pm 0.35$ & $23.54^{*}$ & $<.05$ \\
\hline 1 & $7.5 \times 10^{6}$ & $7.78 \pm 0.36$ & & \\
\hline 4 & $1.0 \times 10^{6}$ & $3.67 \pm 0.35$ & 1.000 & $>.05$ \\
\hline 2 & $0.0 \times 10^{6}$ & $0.00 \pm 0.00$ & & \\
\hline 4 & $1.0 \times 10^{6}$ & $3.48 \pm 0.00$ & -0.981 & $>.05$ \\
\hline 3 & $2.0 \times 10^{6}$ & $7.24 \pm 0.239$ & & \\
\hline
\end{tabular}

${ }^{*}$ Shows a significant difference at $\mathrm{P}<0.05$ level dpi- day post-infection

Table 4: Salmonellae count for broilers fed antibiotic/probiotic $10 \mathrm{dpi}$

The Salmonellae count in faecal materials of broilers in the different treatment groups 15 days post-infection with Salmonella enteritidis; were significantly different $(\mathrm{p}<0.05)$ between birds in treatment G1 (7.35 \pm 0.13$)$ and G4 (0.00 \pm 0.00$)$, and also G2 (7.36 \pm 0.00 ) is significantly different from G4 (Table 5). There were no differences among the Salmonella counts from faecal materials analysed for the broilers in other treatment groups. Table 6 shows the Salmonellae count in faecal materials of broilers in the different treatment groups 18 days post-infection were different at $\mathrm{p}<0.05$ between G1 and G2; and also between G1 and G3. There were no differences among the Salmonella count s from faecal materials analysed from broilers in other treatment groups.

\begin{tabular}{|c|c|c|c|c|}
\hline Group & Mean CFP / ml & LogCFU (mean \pm SEM $)$ & t-value & P \\
\hline 2 & $4.0 \times 10^{6}$ & $7.36 \pm 0.00$ & 2.39 & $>.05$ \\
\hline 1 & $2.5 \times 10^{6}$ & $7.35 \pm 0.13$ & & \\
\hline 3 & $0.5 \times 10^{6}$ & $3.50 \pm 0.00$ & -1.11 & $>.05$ \\
\hline 1 & $2.5 \times 10^{6}$ & $7.35 \pm 0.13$ & & \\
\hline 3 & $0.5 \times 10^{6}$ & $3.50 \pm 0.00$ & -1.171 & $>.05$ \\
\hline 2 & $4.0 \times 10^{6}$ & $7.36 \pm 0.00$ & & \\
\hline 4 & $0.0 \times 10^{6}$ & $0.00 \pm 0.00$ & $12.00^{*}$ & $<.05$ \\
\hline 1 & $2.5 \times 10^{6}$ & $7.35 \pm 0.13$ & & \\
\hline 4 & $0.0 \times 10^{6}$ & $0.00 \pm 0.00$ & $12.43^{*}$ & $<.05$ \\
\hline 2 & $4.0 \times 10^{6}$ & $7.36 \pm 0.00$ & & \\
\hline 4 & $0.0 \times 10^{6}$ & $0.00 \pm 0.00$ & -1.00 & $>.05$ \\
\hline 3 & $0.5 \times 10^{6}$ & $3.50 \pm 0.00$ & & \\
\hline
\end{tabular}

* Shows a significant difference at $\mathrm{P}<0.05$ level dpi- day post-infection

Table 5: Salmonellae count for broilers fed antibiotic/probiotic $15 \mathrm{dpi}$ 
Table 7 shows the Salmonellae count in faecal materials of broilers in the different treatment groups 21 days post-infection with Salmonella Enteritidis; there were significant differences $(\mathrm{p}<0.05)$ between G1 and G2; and also between G1 and G4. There were no differences among the Salmonella count s from faecal materials analysed from broilers in other treatment groups.

\begin{tabular}{|c|c|c|c|c|}
\hline Group & $\begin{array}{c}\text { Mean CFP } \\
/ \mathbf{m l}\end{array}$ & $\begin{array}{c}\text { LogCFU } \\
(\mathbf{m e a n} \pm \text { SEM) }\end{array}$ & t-value & $\mathbf{P}$ \\
\hline 2 & $0.0 \times 10^{6}$ & $7.00 \pm 0.00$ & $-24.33^{*}$ & $<.05$ \\
\hline 1 & $2.5 \times 10^{6}$ & $7.35 \pm 0.30$ & & \\
\hline 3 & $0.0 \times 10^{6}$ & $0.00 \pm 0.00$ & $-24.33^{*}$ & $<.05$ \\
\hline 1 & $2.5 \times 10^{6}$ & $7.35 \pm 0.30$ & & \\
\hline 3 & $0.0 \times 10^{6}$ & $0.00 \pm 0.00$ & 0.00 & $>.05$ \\
\hline 2 & $0.0 \times 10^{6}$ & $0.00 \pm 0.00$ & & \\
\hline 4 & $0.5 \times 10^{6}$ & $3.00 \pm 0.35$ & 1.082 & $>.05$ \\
\hline 1 & $2.5 \times 10^{6}$ & $7.35 \pm 0.30$ & & \\
\hline 4 & $0.5 \times 10^{6}$ & $3.00 \pm 0.35$ & 1.000 & $>.05$ \\
\hline 2 & $0.0 \times 10^{6}$ & $0.00 \pm 0.00$ & & \\
\hline 4 & $0.5 \times 10^{6}$ & $3.00 \pm 0.35$ & 1.000 & $>.05$ \\
\hline 3 & $0.0 \times 10^{6}$ & $0.00 \pm 0.00$ & & \\
\hline
\end{tabular}

*Shows a significant difference at $\mathrm{P}<0.05$ level dpi- day post-infection Table 6: Salmonellae count for broilers fed antibiotic/probiotic $18 \mathrm{dpi}$

\begin{tabular}{|c|c|c|c|c|}
\hline Group & $\begin{array}{c}\text { Mean CFP } \\
/ \mathbf{m l}\end{array}$ & $\begin{array}{c}\text { LogCFU } \\
(\mathbf{m e a n} \pm \text { SEM) }\end{array}$ & t-value & P \\
\hline 2 & $3.5 \times 10^{6}$ & $7.39 \pm 0.00$ & $18.95^{*}$ & $<.05$ \\
\hline 1 & $0.0 \times 10^{6}$ & $0.00 \pm 0.00$ & & \\
\hline 3 & $1.5 \times 10^{6}$ & $3.97 \pm 0.00$ & 1.000 & $>.05$ \\
\hline 1 & $0.0 \times 10^{6}$ & $0.00 \pm 0.00$ & & \\
\hline 3 & $1.5 \times 10^{6}$ & $3.97 \pm 0.00$ & -0.971 & $>.05$ \\
\hline 2 & $3.5 \times 10^{6}$ & $7.39 \pm 0.00$ & & \\
\hline 4 & $14.5 \times 10^{6}$ & $2.37 \pm 0.56$ & $13.92^{*}$ & $<.05$ \\
\hline 1 & $0.0 \times 10^{6}$ & $0.00 \pm 0.00$ & & \\
\hline 4 & $14.5 \times 10^{6}$ & $2.37 \pm 0.56$ & 1.091 & $>.05$ \\
\hline 2 & $3.5 \times 10^{6}$ & $0.00 \pm 0.00$ & & \\
\hline 4 & $14.5 \times 10^{6}$ & $2.37 \pm 0.56$ & 1.087 & $>.05$ \\
\hline 3 & $1.5 \times 10^{6}$ & $3.97 \pm 0.00$ & & \\
\hline
\end{tabular}

* Shows a significant difference at $\mathrm{P}<0.05$ level dpi- day post-infection Table 7: Salmonellae count for broilers fed antibiotic/probiotic $21 \mathrm{dpi}$

The mortality pattern of birds in the different treatment groups fed diet containing probiotic/antibiotic and experimentally infected with Salmonella Enteritidis is as shown in Figure 2. G2, having broilers without probiotic included in the feed before infection with S. Enteritidis has the highest mortality (35.6\%), and the least recorded in G1 (4.4\%) over a rearing period of 8 weeks (Appendix 1).

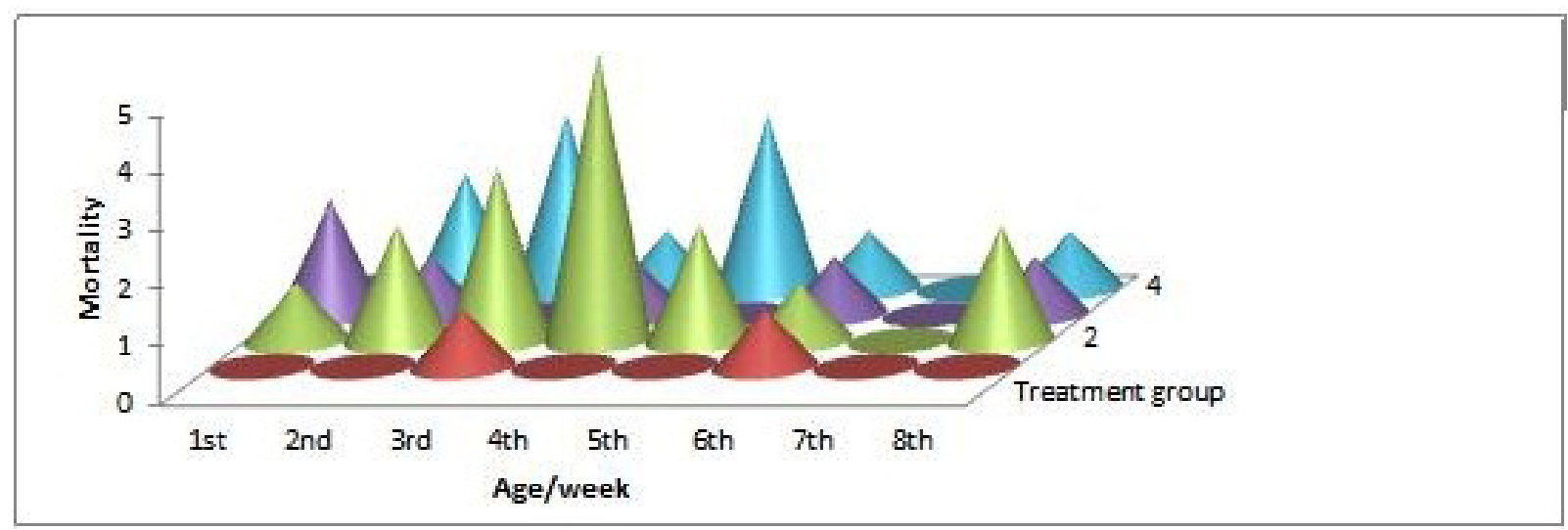

Figure 2: Periodic mortality pattern of broilers fed antibiotic/probiotic diet and experimentally infected with $S$. enteritidis 


\begin{tabular}{|c|c|c|c|c|c|c|c|c|c|c|}
\hline Mortality/week - & & & & & & & & & & \\
\hline Treatment group & $1^{\text {st }}$ & $2^{\text {nd }}$ & $3^{\text {rd }}$ & $4^{\text {th }}$ & $5^{\text {th }}$ & $6^{\text {th }}$ & $7^{\text {th }}$ & $8^{\text {th }}$ & Total & $\%$ \\
\hline 1 & 0 & 0 & 1 & 0 & 0 & 1 & 0 & 0 & 2 & 4.4 \\
\hline 2 & 1 & 2 & 3 & 5 & 2 & 1 & 0 & 2 & 16 & 35.6 \\
\hline 3 & 2 & 1 & 0 & 1 & 0 & 1 & 0 & 1 & 6 & 13.3 \\
\hline 4 & 0 & 2 & 3 & 1 & 3 & 1 & 0 & 1 & 11 & 24.4 \\
\hline
\end{tabular}

Appendix 1: Mortality pattern of broilers fed diet containing probiotic/antibiotic and infected with $S$. enteritidis

\section{Discussion}

More often than not in livestock industry generally, salmonella bacteria are strongly adapted to poultry, and often go without provoked health problems in subclinical infections and remain as intermittent or persistent healthy carriers of the organisms; they may infect or contaminate flocks without causing disease symptoms. However these Salmonella's may contaminate poultry products provoking food poisoning in human beings [34,35]. The prevalence of Salmonella in poultry populations is considered as the main risk factor for presence of Salmonella organisms in poultry meat, poultry products, faecal materials and the environment $[8,36,37]$. The horizontal transmission of salmonella organisms in poultry is as a result of consumption of contaminated feed and water, arising from their faeces because it has been established that poultry manures, faeces and feeds contain significant amounts of nitrogen because of the presence of high levels of protein and amino acids $[13,37,38]$ Faecal shedding of salmonella organism is therefore a way of perpetuating and spreading salmonella organisms in nature.

The design of this study was done in such a way as to show the effects of probiotics on the bacterial count (Salmonella); as established infection in the birds will produce a pattern of intermittent shedding of the bacteria which will be significantly different from the groups where clinical or subclinical infections were not established. The results obtained from this study, however indicated that following the experimental infection with live and viable Salmonella Enteritidis, infection was established as shown by the varied results across the treatment groups. The significant differences among the groups when compared also showed a pattern indicative of the effects of probiotic on the level of faecal shedding of the organism. The total mean count of $S$. Enteritidis obtained from this study showed a pattern where the faecal shedding were higher in G2 chickens than the other Groups fed diet containing probiotics, which is also in agreement with the research findings of Kabir and Zhao \& Xiuping [16,37].

The G4 birds, which is the control group (had antibiotics to clear the gut microbiota against pathogens acquired from the hatcheries; also fed the same broiler starter feed but without probiotic, and given water from the same source) showed a lower significant difference $\mathrm{p}<0.05$ level in the Salmonella excretion when compared to G2 over the period of the experiment.

It is quite remarkable to note that the Group 1 birds (given antibiotics the first five days of life, fed with diet containing probiotics and inoculated with Salmonella Enteritidis) showed a marked significant difference at $\mathrm{p}<0.05$ level when compared to the Group 2 birds (Birds given antibiotics the first five days of life and inoculated with Salmonella Enteritidis but not fed with probiotics). This is indicative of the fact that the probiotics added to the feed probably had a negative influence on the Salmonella Enteritidis organisms; as that was the only variant factor in the treatment of the groups. This is in line with the findings of Yaman, et al. Mountzouris, et al. and Higgins, et al. and could have been responsible for the low levels of faecal excretion of the organisms observed in the G1 birds; this also supports claims by the producers that probiotics usage in feed has an effect in reducing salmonella shedding in infected birds $[23,27,39,40]$.

The result obtained from Group 2 over a period of time showed an undulation in the shedding of the Salmonella Enteritidis indicative of intermittent shedding of the organism [41]. No significant difference was observed between the G3 birds (birds not given antibiotics, but fed diet containing probiotics and eventually inoculated with Salmonella Enteritidis) and G1 birds, this shows that the administration of antibiotics the first five days of life may not be necessary if probiotics are given early in life. A marked significant difference was however observed between the Group 3 and Group 2 birds indicating the possibility of the effects of probiotic in altering the microbiota and hence of Salmonella in the faecal droppings, while the reverse is the case for G2, possibly because of the development of resistance of the organisms to antibiotics used early in life [42].

Furthermore, following the establishment of the infection, overall mortality recorded was highest for the G2, followed by G4 and G3, while G1, are group of broilers fed diet containing probiotic and antibiotics in water first 5 days of life recorded the least mortality throughout the rearing period, this is in line with the findings of Porter that low-grade damage to the intestinal tract by pathogenic bacteria can affect the rate of body weight gain in poultry flocks, but more severe enteric damages by salmonella infections will result in clinical disease and high mortality. This mortality trend could also be as a result of S. Enteritidis tendency to evade or regulate recognition by the host innate immune system $[43,44]$.

There is a significant difference in \% mortality recorded across the treatment groups, 35.6\% was recorded for G2 (control), while G1 had $4 \%$ and G4 without antibiotic also recorded $24.4 \%$ mortality which is in consonance with the findings of [30,45-47]. There is 
variation in the \% mortality recorded between the antibiotics group and the probiotic groups probably because of the development of resistance of the gut microbes to antibiotics $[42,48]$. Peak mortality was observed in G2 at $4^{\text {th }}$ week of life (Figure 2), which coincides with peak salmonellae count for G2 also at 10 days post infection (Figure 1), there is a direct correlation between \% mortality and salmonella shedding; this can also be attributed to the aforementioned reasons of competitive exclusion and bacterial resistance of salmonella organisms [31,42].

\section{Conclusion}

Prevention of the outbreak of an endemic or epidemic disease is a far better approach than treating or controlling such in a poultry flock following an outbreak. This study has shown that Probiotic supplementation in commercial broiler ration will improve; the overall broiler performance, the liveability by causing reduction in percentage mortality throughout the production cycle, will fortify the immunity of the birds to salmonella challenge, and reduce to the barest minimum salmonella faecal shedding. Probiotic supplementation is recommended to be used in poultry at a dose rate of $500 \mathrm{~g} /$ tonne of feed, from the first day of life to slaughter age.

\section{References}

1. Alves LMC, Costa NF, Silva MS, Sales SS, Correia MR (2001) Food poisoning by Salmonella enteritidis: report of an outbreak in Säo Luís - MA / Salmonella food poisoning. Hig Alimentar 15: 57-8.

2. Santos LR, Nascimento VP, Flores ML, Rosek H, D’Andrea A, et al. (2002) Salmonella Enteritidis isoladas de amostras clinicas de humanos e de alimentos envolvidos em episódios de toxinfecções alimentares, ocorridas entre 1995 e 1996, no Estado do Rio Grande do Sul. Rev Hig Alimentar 6: 93-9.

3. Tessari ENC, Kamashiro AMI, Stoppa GFZ, Luciano RL, De Castro AGM, et al. (2012) Salmonella - A Dangerous Foodborne Pathogen, book edited by Barakat S. M. Mahmoud, Chapter 9, Intech publishers. ISBN 978-953-307-782-6.

4. Antunes P, Réu C, Sousa JC, Peixe L, Pestana N (2003) Incidence of Salmonella from poultry products and their susceptibility to antimicrobial agents. International J F Microbiol 82: 97-103.

5. Rajagopal R, Mini M (2013) Outbreaks of salmonellosis in three different poultry farms of Kerala, India. Asi Pac J Trop Biomed 3: 496-500.

6. Mulder RWA (1999) Hygiene during transport, slaughter and processing. In: Poultry meat science. Richardson \& Mead (Eds.), Poult sci. symposium series 25: 277-85.

7. Fernandes SA, Tavechio AT, Ghilardi AC, Dias AM, Almeida IA, et al. (2006) Salmonella serovars isolated from humans in São Paulo State, Brazil, 1996-2003. Rev Inst Med Trop Sao Paulo 48: 179-84.

8. Hugas M, Beloeil PA (2014) Controlling Salmonella along the food chain in the European Union - progress over the last ten years. Eur Surveill 19: 20804.

9. Owen MD (2016) Salmonella Infection in Emergency Medicine, background, pathophysiology and epidemiology.

10. Cardoso ALSP, Tessari ENC, Castro AGM, Kanashiro AMI, Gama NMSQ (2002) Pesquisa de Salmonella spp em ovos comerciais, analisados no Laboratório de Patologia avícola de Descalvado, SP. Rev Hig Alimentar 16: 76-9.

11. Kottwitz LBM, Oliveira TCRM, Alcocer I, Farah SMSS, Abrahao WSM, et al. (2010) Avaliação epidemiológica de surtos de salmoneloses ocorridos no período de 1999 a 2008 no Estado do Paraná, Brasil. Acta Sci Health Sci 32: 9-15.

12. Foley SL, Nayak R, Hanning IB, Johnson TJ, Han J, et al. (2011) Population dynamics of Salmonella enteric serotypes in commercial poultry production. J Appl Environ. Microbiol 77: 4273-9.

13. Sahu RK, Patil S, Lalsangzuala C (2015) Salmonellosis in Poultry - An Overview. Inter J Liv Res 5: 10-20.

14. Van Immerseel F, De Zutter L, Houf K, Pasmans F, Haesebrouck F, et al. (2009) Strategies to control Salmonella in the broiler production chain. W Poult Sci J 65: 367-92.

15. Trafalska E, Grzybowska K (2004) Probiotics-An alternative for antibiotics? Wiad Lek 57: 491-8.

16. Kabir SML (2009) The Role of Probiotics in the Poultry Industry. Int J Mol Sci 10: 3531-46.

17. Griggs JP, Jacob JP (2005) Alternatives to antibiotics for organic poultry production. J Appl Poult Res 14: 750-6.

18. Nava GM, Bielke LR, Callaway TR, Castañeda MP (2005) Probiotic alternatives to reduce gastrointestinal infections: The poultry experience. Ani Hlth Res Rev 6: $105-18$.

19. Zulkifli I, Abdullah N, Azrin NM, Ho YW (2000) Growth performance and immune response of two commercial broiler strains fed diets containing Lactobacillus cultures and oxytetracycline under heat stress conditions. B Poult Sci J 41: 593-7.

20. Kabir SML, Rahman MM, Rahman MB, Rahman MM, Ahmed SU (2004) The dynamics of probiotics on growth performance and immune response in broilers. Int J Poult Sci 3: 361-4.

21. Islam MW, Rahman MM, Kabir SML, Kamruzzaman SM, Islam MN (2004) Effects of probiotics supplementation on growth performance and certain haematobiochemical parameters in broiler chickens. B J Vet Med 2: 39-43.

22. Khaksefidi A, Ghoorchi T (2006) Effect of probiotic on performance and immunocompetence in broiler chicks. J Poult Sc 43: 296-300.

23. Mountzouris KC, Tsirtsikos P, Kalamara E, Nitsch S, Schatzmayr G, et al. (2007) Evaluation of the efficacy of probiotic containing Lactobacillus, Bifidobacterium, Enterococcus, and Pediococcus strains in promoting broiler performance and modulating caecal microflora composition and metabolic activities. Poult Sci 86: 309-17.

24. Willis WL, Reid L (2008) Investigating the effects of dietary probiotic feeding regimens on broiler chicken production and Campylobacter jejuni presence. Poult Sci 87: 606-11.

25. Apata DF (2008) Growth performance, nutrient digestibility and immune response of broiler chicks fed diets supplemented with a culture of Lactobacillus bulgaricus. J Sci F Agric 88: 1253-8.

26. Kabir SML, Rahman MM, Rahman MB, Hosain MZ, Akand MSI, et al. (2005) Viability of probiotics in balancing intestinal flora and effecting histological changes of crop and caecal tissues of broilers. Biotech 4: 325-30. 
27. Higgins JP, Higgins SE, Vicente JL, Wolfenden AD, Tellez G, et al. (2007) Temporal effects of lactic acid bacteria probiotic culture on Salmonella in neonatal broilers. Poult Sci 86: 1662-6.

28. Nayebpor M, Farhomand P, Hashemi A (2007) Effects of different levels of direct fed microbial (Primalac) on growth performance and humoral immune response in broiler chickens. J Ani Vet Adv 6: 1308-13.

29. Dhama K, Verma V, Sawant PM, Tiwari R, Vaid RK, et al. (2011) Applications of Probiotics in Poultry: Enhancing Immunity and Beneficial Effects on Production Performances and Health - A Review J Immunol Immunopathol 13: 1-19.

30. Okuneye OJ, Ogunfolabo LA, Fasanmi OG, Adekunle OF, Oloso NO (2016) Performance and Physiological Responses of Salmonella Enteritidis Challenged Broilers Fed Diets Containing Antibiotic, Probiotic and Aromabiotic. JDVAR 3: 00081.

31. Theodore KJ (2012) How to Use Probiotics to Keep Chickens Healthy. Poultry One.com.

32. Barrell RA (1982) Isolations of Salmonellas from human, food and environmental sources in the Manchester area 1976-1980. J Hyg (London) 88: 403-9.

33. Steigh JD, Duguid JP (1989) Salmonella $13^{\text {th }}$ edn Collee JG, Duguid JP, Fraser AG, Marmion BP, editors. Practical Medical Microbiology, Vol. 2. New York: Churchill Livingstone 456-79.

34. Todar K (2008) Todars Online Textbook of Bateriology.

35. Soncini RA (2014) Reducing risks of Salmonella infections in poultry. WP Special issue.

36. Regulation (EC) No 2160/2003 of the European Parliament and of the Council and Regulation of 17 November 2003 on the control of salmonella and other specified food-borne zoonotic agents. OJ L 325, 12.12.2003, 1-15.

37. Zhao C, Xiuping J (2014) Microbiological Safety of Chicken Litter or Chicken Litter- Based Organic Fertilizers: A Review. Agric 4: 1-29.

38. Orji MU, Onuigbo HC, Mbata TI (2005). Isolation of Salmonella from poultry droppings and other environmental sources in Awka, Nigeria. Int J Infect Dis 9: 86-9.

39. Yaman H, Ulukanli Z, Elmali M, Unal Y (2006) The effect of a fermented probiotic, the kefir, on intestinal flora of poultry domesticated geese (Anser anser). Rev Méd Vét 157: 379-86.

40. Biomin (2011) Using probiotics in a practical way. World Poultry 27: 24-5.

41. Shivaprasad HL, Timoney JF, Morales S, Lucio B, Baker RC (1990) Pathogenesis of Salmonella enteritidis infection in laying chickens. I. Studies on egg transmission, clinical signs, faecal shedding, and serologic responses. Av Dis 34: 548-55.

42. Manic M, Nikolic S, Marjanovic V, Antanasijevic S, Raicevic Z, Petrovic M (2016) Resistance Testing of Salmonella Spp. Bacteria Isolated from Samples Derived from Poultry on Antimicrobial Drugs. JDVAR 3: 00074

43. Porter RE (1998) Bacterial enteritides of poultry. Poultry Sciences 77: 1159-65.

44. Revolledo L, Ferreira AJP (2012) Current perspectives in avian salmonellosis: Vaccines and immune mechanisms of protection. J Appl Poult Res 21: 418-31.

45. Khosravina H (2015) Effect of dietary supplementation of medium-chain fatty acids on growth performance and prevalence of carcass defects in broiler chickens raised in different stocking densities. J Appl Poult Res 00: 1-9.

46. Fasanmi OG, Oladele-Bukola MO, Balogun FA, Olona JF, Okuneye OJ (2015) Growth performance characteristics haematology and serum biochemistry of finisher broilers fed diet containing aromabiotic and neobacin. Global J Animal Science Livestock Production and Animal Breeding 3: $133-7$.

47. World Poultry (2016) Benefits of probiotic-fed Poultry.

48. Apata DF (2009) Antibiotic Resistance in Poultry. Int J Poult Sci 8: 404-8.

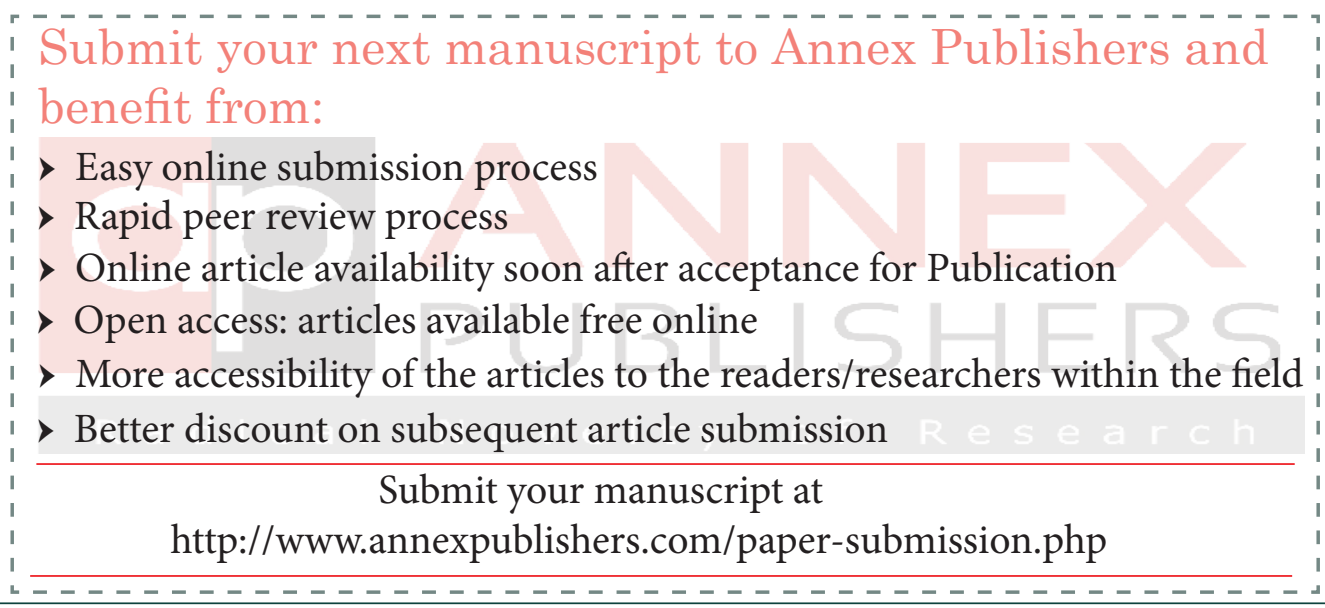

